\title{
PENGARUH E-MODUL BERBASIS MODEL PEMBELAJARAN PROJECT BASED LEARNING PADA MATA PELAJARAN VIDEOGRAFI TERHADAP HASIL BELAJAR SISWA KELAS XI DESAIN KOMUNIKASI VISUAL DI SMK NEGERI 1 SUKASADA
}

\author{
Pande Gede Erick Suryadi $^{1}$, Ketut Agustini ${ }^{2}$, Nyoman Sugihartini ${ }^{3}$ \\ 1Jurusan Pendidikan Teknik Informatika/ Fakultas Teknik Dan Kejuruan/ \\ Universitas Pendidikan Ganesha
}

e-mail: pandesuryadi83@gmail.com ${ }^{1}, \underline{\text { ketutagustini@undiksha.ac.id }}^{2}, \underline{\text { sugihartini@undiksha.ac.id }}^{3}$

\begin{abstract}
Abstrak
Tujuan penelitian ini adalah untuk mengetahui (1) pengaruh perbedaan hasil belajar antara siswa yang belajar menggunakan e-modul dengan siswa yang menggunakan menggunakan bahan ajar LKS, Video dan sumber dari guru pada mata pelajaran Videografi Siswa Kelas XI DKV SMK Negeri 1 Sukasada, (2) untuk mengetahui respon siswa setelah menggunakan e-modul berbasis project based learning mata pelajaran Videografi. Jenis penelitian ini adalah eksperimen semu dengan rancangan Post Test Only Control Group Design. Pengumpulan daya dilakukan dengan metode esei untuk mengatur ranah kognitif. Data hasil belajar di analisis melalui uji prasyarat yaitu uji normalitas dan uji homogenitas dengan hasil kedua kelompok berdistribusi normal dan homogen, dilanjutkan dengan uji hipotesis dengan menggunakan uji-t. hasil menyatakan terdapat perbedaan hasil belajar antara siswa yang belajar menggunakan e-modul dengan siswa yang menggunakan menggunakan bahan ajar LKS, Video dan sumber dari guru. Kemudian dilihat dari rata-rata hasil belajar, rata-rata kelas eksperimen adalah 19 dan kelas control adalah 17 maka dapat disimpulkan bahwa media pembelajaran emodul mendapatkan rata-rata yang lebih tinggi dari media pembelajaran yang bersumber dari guru.
\end{abstract}

Kata kunci: Videografi, E-modul, Hasil Belajar, Project Based Learning.

\begin{abstract}
The purpose of this research is to know (1) learning outcomes differences between students that use e-module as learning media with students that use confessional learning media (textbooks, videos, etc) on videography subject in XI DKV class, SMK Negeri 1 Sukasada (2) student response that use e-module with project-based learning method in videography subject. This is a quasi-experimental research with Post Control Only Control Group Design. Data is collected by an essay to measure in cognitive area. Learning result data is analyzed by prerequisite test namely normality test and homogeneity test, with the result of both groups, are normal and homogeneous distributed. Followed by hypothesis testing using t-test. The results show there are differences in learning outcomes between students that use e-module as learning media with students that use confessional learning media on videography subject. Seen from the average of learning outcomes, the average of the experimental class is 19 and the control class is 17, so it can be concluded that e-module get a higher average than the confessional learning media that comes from the teacher.
\end{abstract}

Keywords : Videography, E-modul, Learning Outcome, Project Based Learning. 


\section{PENDAHULUAN}

Teknologi informasi sudah tidak asing lagi bagi masyarakat saat ini, baik itu negara maju maupun negara berkembang. Teknologi berkembang pesat dan memengaruhi kehidupan masyarakat. Didalam pedidikan teknologi saat ini sangat diperlukan untuk bisa mencari dan juga mendapatkan informasi terkait pendidikan. Pendidikan merupakan upaya untuk meningkatkan kualitas masyarakat atau SDM. Dalam meningkatkan sumber daya manusia yang berkualitas diperlukan strategi pembelajaran yang diharapkan mampu memperbaiki sistem pendidikan yang telah berlangsung selama ini ${ }^{[1]}$. Maka dari itu peningkatan kualitas pendidikan merupakan hal penting yang diperlukan saat ini. Kualitas pendidikan di pengaruhi oleh banyak faktor seperti rendahnya kualitas sarana fisik dan banyak sekali sekolah yang gedungnya rusak, kepemilikan dan penggunaan media belajar rendah.

Dalam hal bahan ajar belum semua sekolah mempunyai kesempatan memperoleh bahan ajar yang cukup, baik dari segi kualitas maupun dari segi kuantitasnya. Ketersediaan bahan ajar yang masih kurang dikarenakan masih terbatasnya alokasi dana dan masih tersentralisasinya pengadaan bahan ajar, mengakibatkan sumber daya manusia yang ada di daerah sekolah - sekolah dalam hal ini guru belum dimanfaatkan seoptimal mungkin. Khususnya dalam bidang pengembangan bahan ajar. Media elektronik yang dapat diakses oleh siswa mempunyai manfaat dan karakteristik yang berbeda-beda ${ }^{[2]}$.

SMK Negeri 1 Sukasada merupakan salah satu sekolah menengah kejuruan Seni dan Teknologi di kabupaten Buleleng yang bertanggung jawab dalam mengembangkan minat dan bakat yang dimiliki oleh peserta didik. Sebagai sebuah sekolah kejuruan, SMK 1 Sukasada senatiasa berupaya untuk meningkatkan mutu dari segala aspek sehingga diharapkan nantinya akan memberikan dampak terhadap lulusan yang mempunyai kualitas kompetensi yang siap bersaing di dunia kerja. SMK Negeri 1 Sukasada memiliki beberapa program keahlian salah satunya adalah program keahlian desain komunikasi visual, terdapat pembelajaran khusus di dalam jurusan ini yaitu pembelajaran produktif. Salah satu kompetensi keahlian yang termasuk mata pelajaran Produktif pada jurusan Desain Komunikasi Visual yaitu Videografi. Mata pelajaran Videogarafi adalah salah satu mata pelajaran produktif yang ada di SMK Negeri 1 Sukasada dimana kurikulum yang digunakan adalah kurukulum KTSP. Kurikulum KTSP adalah pembelajaran berpusat pada siswa, dimana siswa mencari pengetahuan bukan menerima pengetahuan oleh karena itu proses pembelajaran produktif di SMK sebaiknya dilakukan dengan student centered yakni berpusat pada siswa, sehingga bisa menumbuhkan kemampuan berfikir, bekerja dan memecahkan masalah dengan cara siswa itu sendiri, oleh karena itu pembelajaran di SMK menekankan pada kemandirian siswa serta memberikan pengalaman belajar secara langsung tentang materi yang dipelajari.

Tahap belajar dengan model pembelajaran Project Based Learning ini dipilih untuk mengubah gaya belajar yang berpusat pada guru menjadi pembelajaran yang berpusat pada siswa dengan cara memberikan ruang kepada siswa untuk menumbuhkan kreativitas sehingga menghasilkan suatu produk sebagai pemecahan masalah yang dihadapi. Keuntungan model pembelajaran Project Based Learning antara lain: (1) Increased motivation, (2) Increased problem-solving ability, (3) Improved library research skills, (4) Increased collaboration, dan (5) Increased resource-management skills. Elearning pendukung project based learning berhasil dibangun menggunakan Ims moodle dapat digunakan sebagai salah satu alternatif dalam proses belajar mengajar dan $92 \%$ responden menyatakan bahwa elearning mudah diakses dan sebanyak $76 \%$ 
responden menyatakan bahwa e-learning mudah digunakan ${ }^{[3]}$. Moodle memiliki fitur sangat lengkap mencangkup manajemen materi dan aktifitas pembelajaran ${ }^{[4]}$.

Berdasarkan observasi awal yang dilakukan dengan teknik wawancara beserta angket terhadap guru pengampu mata pelajaran Videografi pada tanggal 03 Maret 2017 dengan bapak I Putu Suwarbawa.S.Pd.,M.Ds diperoleh data bahwa sumber belajar ataupun bahan ajar yang dipakai untuk kegiatan belajar mengajar hanya sebatas video dan buku digital atau yang dering disebut e-book. Didalam pembelajaran Videografi kendala yang terjadi yaitu masalah alat yang digunakan saat proses pembelajaran yang kurang memadai seperti contohnya : kamera dan komputer yang belum memiliki spesifikasi yang tinggi sehingga tidak semua siswa saat mengikuti kegiatan pembelajaran mendapatkan alat dan sarana praktikum yang baik, meskipun siswa - siswa disana memiliki karakteristik yang selalu inggin tahu saat proses pembelajaran berlangsung dan memiliki semangat belajar yang tinggi namun karena media dan alat pembelajaran tidak memadai maka mereka merasa bosan dan cendrung hanya sekadar melihat dan mendengarkan penjelasan dari guru, untuk itu media pembelajaran yang digunakan oleh guru sangatlah besar pengaruhnya dalam membantu proses kegiatan belajar mengajar. Penggunaan media pembelajaran secara tepat, dan bervariasi dapat mengatasi sikap pasif anak didik ${ }^{[5]}$.

Sebuah penelitian dengan judul "Pengembangan E-Modul Berbasis Model Pembelajaran Project Based Learning pada Mata Pelajaran Videografi Untuk Siswa Kelas X Desain Komunikasi Visual Di SMK Negeri 1 Sukasada" oleh I Komang Priatna (2016) dimana modul ini dikembangkan dengan menggunakan model pengembangan Dick and Carey. Hasil penelitian menunjukkan bahwa : (1) Hasil rancangan dan implementasi Pengembangan E-Modul Berbasis Model Pembelajaran Project Based Learning Pada Mata Pelajaran Videografi untuk Siswa Kelas X Desain Komunikasi Visual di Smk
Negeri 1 Sukasada menggunakan tahapan model project based learning sudah dinyatakan berhasil diterapkan. $\mathrm{Hal}$ ini dapat dilihat dari rata-rata persentase berdasarkan hasil pengujian yang telah dilakukan. Secara umum siswa terlihat antusias dan lebih aktif selama proses pembelajaran berlangsung. (2) Respon guru terhadap Pengembangan E-Modul Berbasis Model Pembelajaran Project Based Learning Pada Mata Pelajaran Videografi untuk Siswa Kelas $X$ Desain Komunikasi Visual di Smk Negeri 1 Sukasada didapatkan rata-rata sebesar 50 . Jika dikonversikan ke dalam tabel kriteria penggolongan respon maka hasilnya termasuk dalam kategori sangat positif. Sedangkan untuk respon siswa terhadap pengembangan e-modul videografi memperoleh rata-rata sebesar 67,65 . Jika dikonversikan ke dalam tabel kriteria penggolongan respon maka hasilnya termasuk dalam kategori sangat positif.

Terkait dengan hal ini maka timbul minat untuk mengkaji lebih jauh apakah penerapan E-Modul Berbasis Project Based Learning diterapkan pada Mata Pelajaran Videografi untuk kelas XI Desain Komunikasi Visual SMK Negeri 1 Sukasada dengan tujuan ingin mengetahui seberapa besar hasil belajar di sekolah tersebut saat menggunakan E-Modul dalam proses pembelajaran berlangsung. Penelitian yang mungkin dilakukan adalah penelitian eksperimental semu (quasi) dengan pola dasar Post Test Only With Non Equivalent Control Group Design. Dalam penelitian yang berjudul "Pengaruh E-Modul Berbasis Model Pembelajaran Project Based Learning Pada Mata Pelajaran Videografi Terhadap Hasil Belajar Siswa Kelas XI Desain Komunikasi Visual di SMK Negeri 1 Sukasada".

\section{KAJIAN TEORI}

\section{A. Teori Belajar}

Setiap usaha penyelenggaraan jenis dan jenjang pendidikan, belajar merupakan komponen paling urgen, sehingga tanpa proses belajar sesungguhnya tidak pernah ada Pendidikan ${ }^{[6]}$. Untuk menangkap isi dan pesan belajar, dalam belajar tersebut 
individu menggunakan kemampuan pada ranah-ranah (1) kognitif (kognisi), yaitu kemampuan yang berkenaan dengan pengetahuan, penalaran atau pikiran, yang terdiri atas pengetahuan, pemahaman, penerapan, analisis, sintesis, dan evaluasi; (2) afektif (afeksi), yaitu kemampuan yang mengutamakan perasaan, emosi, dan reaksi-reaksi yang berbeda dengan penalaran, yang terdiri atas penerimaan, partisipasi, penilaian/penentuan sikap, organisasi, dan pembentukan pola hidup; dan (3) psikomotorik (konasi), yaitu kemampuan yang mengutamakan keterampilan jasmani, yang terdiri atas persepsi, kesiapan, gerakan terbimbing, gerakan terbiasa, gerakan kompleks, penyesuaian pola gerakan, dan kreativitas.

Learning is change in human disposition or capacity, wich persists over a period time, and which is not simply ascribable to process a growth ${ }^{[7]}$. Belajar adalah perubahan yang terjadi dalam kemampuan manusia setelah belajar secara terus menerus, bukan hanya disebabkan karena proses pertumbuhan saja. Gagne berkeyakinan bahwa belajar dipengaruhi oleh faktor dari luar diri dan faktor dalam diri dan keduanya saling berinteraksi.

\section{B. E-Modul}

E-modul adalah bahan belajar yang dirancang secara sistematis berdasarkan kurikulum tertentu dan dikemas dalam bentuk satuan waktu tertentu yang ditampilkan menggunakan piranti elektronik misalnya komputer atau android ${ }^{[8]}$. E-modul merupakan alat atau sarana pembelajaran yang berisi materi, metode, batasanbatasan, dan cara mengevaluasi yang dirancang secara sistematis dan menarik untuk mencapai kompetensi yang diharapkan sesuai dengan tingkat kompleksitasnya secara elektronik (bagian dari e-learning ${ }^{[9]}$. Selain itu menurut Modul elektronik dapat digunakan dimana saja serta lebih praktis untuk dibawa kemana saja $^{[10]}$.

\section{Project Based Learning}

Pembelajaran berbasis proyek Project Based Learning adalah metode pembelajaran yang menggunakan proyek atau kegiatan sebagai media. Peserta didik melakukan eksplorasi, penilaian, interpretasi, sintesis, dan informasi untuk menghasilkan berbagai bentuk hasil belajar. Pembelajaran berbasis proyek merupakan metode belajar yang menggunakan sebagai langkah awal dalam menggumpulkan dan mengintegrasikan pengetahuan baru berdasarkan pengalamannya dalam beraktivitas secara nyata ${ }^{[12]}$.

Project based learning atau pembelajaran berbasis proyek merupakan model pembelajaran yang berpusat pada peserta didik untuk melakukan suatu investigasi yang mendalam terhadap topik. Peserta didik secara konstruktif melakukan pendalaman pembelajaran dengan pendekatan berbasis riset terhadap permasalahan dan pertanyaan yang berbobot, nyata, dan relevan ${ }^{[11]}$.

\section{Hasil Belajar}

Belajar mengandung pengertian terjadinya perubahan dari persepsi dan prilaku, termasuk juga perbaikan prilaku, misalnya pemuasan kebutuhan masyarakat dan pribadi secara lengkap ${ }^{[12]}$. Perubahperubahan itu dapat berupa hasil yang baru atau pula penyempurnaan terhadap hasil yang diperoleh. Hasil yang diperoleh tersebut yang disebut dengan hasil belajar.

Hasil belajar mengacu pada segala sesuatu yang menjadi milik siswa sebagai akibat dari kegiatan pembelajaran yang dilakukan.

\section{METODE}

\section{A. Jenis Penelitian}

Penelitian ini merupakan penelitian Eksperimen, mengingat tidak semua variabel atau gejala yang muncul dan kondisi eksperimen dapat diatur dan dikontrol secara ketat, maka penlelitian ini dikategorikan penelitian eksperimen semua (quasi experiment) $^{[13]}$.

\section{B. Desain Penelitian}

Desain penelitian yang digunakan adalah post-test only control group design. Desain penelitian ini dipilih karena peneliti 
hanya ingin mengukur hasil belajar siswa sesudah perlakuan.

Desain eksperimen tersebut ditunjukkan pada Gambar berikut.

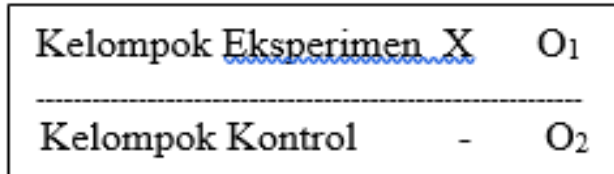

Keterangan :

O1, 02 = Posttest yaitu pemberian tes sesudah perlakuan

\author{
$\mathrm{X}=$ Perlakuan dengan media \\ pembelajaran E-modul Videografi \\ - =Dibelajarkan tanpa media \\ C. Populasi dan Sampel \\ pembelajaran E-modul Videografi

\section{Populasi}

Populasi dalam penelitian ini adalah siswa kelas XI Desain Komunikasi Visual di SMK Negeri 1 Sukasada tahun pelajaran 2017/2018 jumlah total siswa sebanyak 30 siswa. Distribusi jumlah siswa kelas $\mathrm{XI}$ Desain Komunikasi Visual di SMK Negeri 1 Sukasada pada tahun pelajaran 2016/2017 disajikan pada Tabel berikut 1 berikut:

Tabel 1. Populasi Penelitian

\begin{tabular}{|l|l|c|}
\hline No & Kelas & Jumlah Siswa \\
\hline & XI A Desain Komunikasi Visual & 15 \\
\hline & XI B Desain Komunikasi Visual & 15 \\
\hline Jumlah & $\mathbf{3 0}$ \\
\hline
\end{tabular}

\section{Sampel}

Sampel dalam penelitian ini adalah siswa kelas XI DKV B sebagai kelompok eksperimen dan kelas XI DKV A sebagai kelas kelompok kontrol.

Untuk menunjukkan bahwa kedua kelas tersebut setara, maka dapat juga dilakukan pengujian dengan menggunakan Uji-t. Uji-t untuk sampel yang tidak berkorelasi atau terpisah terdiri dari dua jenis rumus, yaitu separated varians dan polled varian pada Persamaan 1 dan Persamaan 2.

Rumus Separated Varians :

$$
\mathrm{t}=\frac{\overline{\mathrm{X}}_{1}-\overline{\mathrm{X}}_{2}}{\sqrt{\frac{\mathrm{s}_{1}^{2}}{\mathrm{n}_{1}}+\frac{\mathrm{s}_{2}^{2}}{\mathrm{n}_{2}}}}
$$

Rumus Polled Varians :

$$
\mathrm{t}=\frac{\overline{\mathrm{X}}_{1}-\overline{\mathrm{X}}_{2}}{\sqrt{\frac{\left(\mathrm{n}_{1}-1\right) \mathrm{s}_{1}^{2}+\left(\mathrm{n}_{2}-1\right) \mathrm{s}_{2}^{2}}{\mathrm{n}_{1}+\mathrm{n}_{1}-2}\left(\frac{1}{\mathrm{n}_{1}}+\frac{1}{\mathrm{n}_{2}}\right)}}
$$

Keterangan :

$\bar{X}_{1}=$ Nilai rata-rata skor kelompok 1

$\bar{X}_{2}=$ Nilai rata-rata skor kelompok 2

$\mathrm{n} 1$ = Banyaknya subjek kelompok 1

n2 = Banyaknya subjek kelompok 2

s12 = varians sampel kelompok 1

s22 = varians sampel kelompok 2

\section{Variabel Penelitan Variabel Bebas}

Variabel bebas merupakan variabel yang mempengaruhi atau yang menjadi sebab perubahannya atau timbulnya variabel dependen (terikat). Dalam penelitian ini adalah media pembelajaran. Media pembelajaran yang digunakan adalah e-modul.

\section{Variabel Terikat}

Variabel terikat merupakan variabel yang dipengaruhi atau yang menjadi akibat, karena adanya variabel bebas. Sesuai dengan variabel terikat dalam penelitian ini adalah hasil belajar siswa pada mata pelajaran Videografi di SMK Negeri 1 Sukasada yang diperoleh setelah proses pembelajaran. Hubungan variabel dalam penelitian ini dapat digambarkan sebagai berikut.

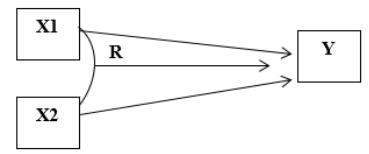

Keterangan :

$\mathrm{X} 1=$ Variabel Bebas $(\mathrm{E}$ - Modul mata pelajaran Videorafi) 


$$
\begin{array}{cc}
\text { X2 Variabel Bebas (LKS, Video } \\
\text { pembelajaran) }
\end{array}
$$

\section{E. Uji Coba Instrumen Penelitian}

Sebelum digunakan, instrumen penelitian pada ranah kognitif diuji terlebih dahulu apakah tes hasil belajar sudah layak digunakan sebagai instrumen penelitian. Instrumen dikatakan sesuai jika instrumen tersebut sudah memenuhi kriteria Validitas,Reliabilitas.

\section{a. Uji Validasi}

Karakteristik pertama dan memiliki peranan yang sangat penting dalam instrumen evaluasi, yaitu karakteristik valid. Instrument yang valid berarti alat ukur yang digunakan untuk mendapatkan data (mengukur) itu valid. Valid berarti instrument tersebut dapat digunakan untuk mengukur apa yang seharusnya diukur. Hasil penelitian yang valid bila terdapat kesamaan antara data yang terkumpul dengan data yang sesungguhnya terjadi pada objek yang diteliti.

\section{F. Uji Reliabilitas}

Pengujian reliabilitas pada penelitian ini menggunakan formula Alpha Cronbach :

$$
\begin{aligned}
& \mathbf{r}_{\mathbf{1 1}}=\left(\frac{\mathbf{k}}{\mathbf{k}-\mathbf{1}}\right)\left(\mathbf{1}-\frac{\sum \sigma_{\mathbf{b}}{ }^{2}}{\sum \sigma_{\mathbf{t}}{ }^{2}}\right) \\
& \text { Keterangan: } \\
& \mathbf{r}_{11}=\text { reliabilitas instrument } \\
& \mathrm{k} \quad=\text { banyaknya butir pertanyaan } \sum \sigma b^{2} \\
& \quad=\text { jumlah varians butir } \\
& \sum \sigma t^{2} \quad=\text { varian total }
\end{aligned}
$$

Kriteria yang digunakan dalam uji reabilitas ini adalah yang terlihat pada Tabel 2 berikut.

Tabel 2. Tingkat Reliabilitas Rumus Alpha Cronbach

\begin{tabular}{|l|l|}
\hline Nilai & Keterangan \\
\hline$r_{11}<0,20$ & Sangat Rendah \\
\hline $0,20 \leq r_{11}<0,40$ & Rendah \\
\hline $0,40 \leq r_{11}<0,60$ & Sedang \\
\hline $0,60 \leq r_{11}<0,80$ & Tinggi \\
\hline $0,80 \leq r_{11}<1,00$ & Sangat Tinggi \\
\hline
\end{tabular}

Semakin tinggi nilai reliabilitas dari sebuah instrumen maka semakin konsisten dan dapat dipercaya instrumen tersebut. Semakin rendah nilai reliabilitas dari intrumen tersebut maka instrumen tersebut tidak konsisten terhadap objek yang diukur.

\section{G. Uji Indeks Kesukaran Butir}

Taraf kesukaran tes adalah kemampuan tes tersebut dalam menjaring banyaknya subjek peserta tes yang dapat mengerjakan dengan betul.

Taraf kesukaran tes dinyatakan dalam indeks kesukaran.

Indek kesukaran butir untuk tes non dikotomi dihitung dengan rumus berikut.

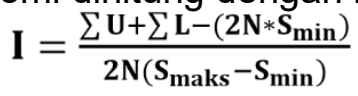

Keterangan:

$\sum U=$ total skor kelompok atas

$\sum L=$ total skor kelompok bawah

$\sum S_{\text {min }}=$ skor maksimum butir.
$\sum_{N} S_{\text {mak }}=$ skor minimum butir

Adapun pembagian tingkat kesukaran kriteria untuk menentukan indeks kesukaran butir adalah sebagai berikut :

- Butir dengan P 0,00 sampai 0,24 tergolong sukar

- Butir dengan P 0,25 sampai 0,74 tergolong sedang

- Butir dengan P 0,75 sampai 1,00 tergolong mudah

\section{H. Uji Indek Daya Beda}

Analisis daya pembeda adalah pengkajian butir-butir soal yang dimaksudkan untuk mengetahui kesanggupan butir-butir tes untuk membedakan siswa yang tergolong mampu dengan siswa yang tergolong tidak mampu. Indeks daya beda tes hasil belajar sesuai persamaan berikut. 


$$
\mathrm{d}=\frac{(\mathrm{n}-1)\left(\mathrm{N}^{2}-\sum \mathrm{f}_{\mathrm{i}}^{2}\right)}{\mathrm{nN}^{2}}
$$

Keterangan:

$$
\begin{array}{ll}
\mathrm{d} & \text { : Indeks daya beda } \\
\mathrm{N} & \text { : banyak peserta tes } \\
\mathrm{fi} & \text { : frekuensi pada tiap tiap skor } \\
\mathrm{n} & \text { : banyak butir }
\end{array}
$$

\section{Teknik Analisis Data}

Data yang diperoleh dalam penelitian ini adalah data kuantitatif dan kualitatif.
Data tersebut diolah menggunakan analisis statistik dan analisis non statistik Analisis deskriptif dilakukan untuk mengetahui tinggi rendahnya kualitas dari hasil belajar. Penentuan kualitas variabel-variabel tersebut, skor rata-rata (mean) tiap-tiap variabel dikonversikan dengan menggunakan kriteria rata-rata ideal dan standar deviasi (SD) seperti terlihat pada Tabel 3 berikut :

Tabel 3. Uji Mean Ideal dan Standar Deviasi Ideal

\begin{tabular}{|l|l|}
\hline Rentangan Skor & Kategori \\
\hline $\mathrm{Mi}+1,5 \mathrm{Si} \leq \mathrm{x}$ & Sangat Positif \\
\hline $\mathrm{Mi}+0,5 \mathrm{Si} \leq \mathrm{x}<\mathrm{Mi}+1,5 \mathrm{Si}$ & Positif \\
\hline $\mathrm{Mi}-0,5 \mathrm{Si} \leq \mathrm{x}<\mathrm{Mi}+0,5 \mathrm{Si}$ & Cukup Positif \\
\hline $\mathrm{Mi}-1,5 \mathrm{Si} \leq \mathrm{x}<\mathrm{Mi}-0,5 \mathrm{Si}$ & Kurang \\
\hline $\mathrm{X}<\mathrm{Mi}-1,5 \mathrm{Si}$ & Sangat Kurang \\
\hline
\end{tabular}

Keterangan :

$\mathrm{X}=$ Kualifikasi nilai

$\mathrm{Mi}=\frac{1}{2}$ (skor tertinggi ideal + skor terendah ideal)

Sdi $=\frac{1}{6}$ (skor tertinggi ideal + skor terendah ideal)

\section{J. Teknik Analisis Uji Asumsi}

Karena menggunakan 2 (dua) kelas dengan perlakuan yang berbeda Data hasil penelitian dianalisis dengan uji-t independent sample t-test. Asumsi yang harus dipenuhi dalam uji-t meliputi (1) data berdistribusi normal dan (2) varians dalam kelompok homogen. Sebelum dianalisis, terlebih dahulu dilakukan uji asumsi. Pengujian asumsi dilakukan untuk mengetahui apakah data yang tersedia dapat dianalisis dengan statistik parametrik atau tidak. Terkait dengan statistik yang digunakan untuk analisis data dalam penelitian ini, maka uji asumsi yang dilakukan adalah uji normalistas dan uji homogenitas.

\section{K. Uji Normalitas}

Uji normalitas sebaran dilakukan untuk menyajikan bahwa sampel benarbenar berasal dari populasi yang berdistribusi normal. Uji normalitas dilakukan untuk menentukan langkah pengujian dengan menggunakan pengujian statistik parametrik atau non parametrik. Hipotesis yang akan diujikan adalah :

$\mathrm{H}_{\mathrm{o}} \quad$ : Data berdistribusi Normal.

$\mathrm{H}_{1}$ : Data tidak berdistribusi Normal. Uji normalitas data dilakukan dengan uji Chi-Square $(\mathrm{X} 2)$ dengan rumus :

$$
\mathrm{X}^{2}=\sum \frac{\left(\mathrm{F}_{0}-\mathrm{F}_{\mathrm{h}}\right)^{2}}{\mathrm{~F}_{\mathrm{h}}}
$$

Keterangan:

$\mathrm{X}^{2}$ : Chi-Square

$F_{0}$ : frekuensi yang diperoleh sampel

$F_{h}$ : frekuensi yang diharapkan

Kriteria pengujian dapat berdistribusi normal jika $\mathrm{X}^{2}$ hit $<\mathrm{X}^{2}$ tab, dengan taraf signifikansi $5 \%$ dan derajat kebebasan $\mathrm{dk}=(\mathrm{k}-1)$.

\section{Uji Homogenitas}

Uji homogenitas ini dilakukan untuk mencari tingkat kehomogenan secara dua pihak yang diambil dari kelompok-kelompok terpisah dari satu populasi yaitu kelompok kontrol dan kelompok eksperimen. Untuk menguji homogenitas varians untuk kedua kelompok digunakan uji $\mathrm{F}$, Hipotesis yang akan diujikan adalah :

$\mathrm{H}_{\mathrm{o}} \quad$ : Tidak ada perbedaan varians antara kelompok kontrol dan kelompok eksperimen (homogen) 
$\mathrm{H}_{1}$ : Ada perbedaan varians antara kelompok kontrol dan kelompok eksperimen (tidak homogen)

Dengan rumus Uji F sebagai berikut:

$$
F_{\text {hit }}=\frac{s_{1}{ }^{2}}{s_{2}{ }^{2}}
$$

Keterangan :

$\mathrm{s}_{1}{ }^{2} \quad$ : varians terbesar

$\mathrm{s}_{2}{ }^{2} \quad$ : varians terkecil

Kriteria pengujian, jika Fhit $F_{\text {hit }} \geq$ $F_{\alpha(n 1-1, n 2-1)}$ maka sampel tidak homogen dapat melakukan pengujian dengan menggunakan rumus polled varians dan jika $F_{\text {hit }} \geq F_{\alpha(n 1-1, n 2-1)}$ maka sampel homogen dapat melakukan pengujian dengan dengan menggunakan rumus separated varians. Pengujian dilakukan pada taraf signifikan $5 \%$ dengan derajat kebebasan untuk pembilang $n_{1}-1$ dan derajat kebebasan untuk penyebut $n_{2}-1$.

\section{Uji Hipotesis}

Uji hipotesis digunakan untuk menguji hipotesis yang telah dilakukan pada penelitian ini, yaitu terdapat perbedaan yang signifikan terhadap hasil belajar materi Videografi siswa antara siswa yang mengikuti pembelajaran dengan e-modul dengan siswa yang mengikuti pembelajaran dengan sumber belajar dari guru (LKS) pada siswa kelas XI DKV SMK Negeri 1 Sukasada. Pengujian hipotesis dijabarkan menjadi hipotesis nol $\left(\mathrm{H}_{0}\right)$ melawan hipotesis alternatif $\left(\mathrm{H}_{1}\right)$.

Secara statistik hipotesis tersebut dapat dirumuskan sebagai berikut:

$\mathrm{H}_{0}: \mu_{1}=\mu_{2}$ melawan $\mathrm{H}_{1}=\mu_{1}>\mu_{2}$

Artinya adalah :

$\mathrm{H}_{0}: \mu_{1}=\mu_{2} \quad$ : tidak terdapat perbedaan hasil belajar antara siswa yang belajaran menggunakan e-modul dengan siswa yang belajaran tanpa menggunakan e- modul pada kelas XI DKV SMK Negeri 1 Sukasada.

$\mathrm{H}_{1}: \mu_{1}>\mu_{2} \quad$ : terdapat perbedaan hasil belajar antara siswa yang belajaran menggunakan e-modul dengan siswa yang belajaran tanpa menggunakan e- modul pada kelas XI DKV SMK Negeri 1 Sukasada. Keterangan : $\mu_{1}=$ skor rata-rata hasil belajar siswa kelas eksperimen (KE)

$\mu_{2}=$ skor rata-rata hasil belajar siswa kelas kontrol (KK)

Teknik analisis data yang digunakan untuk menguji hipotesis yaitu menganalisis perbedaan antara dua kelompok skor. Jika terbukti bahwa data yang dikumpulkan berdistribusi normal dan homogen ataupun tidak homogen, maka untuk menguji hipotesis pada penelitian ini akan digunakan uji-t dengan taraf signifikan $5 \%$. $T$-tes yang digunakan adalah pooled varian ataupun sparated varian. Pengujian hipotesis menggunakan t-test terdapat beberapa rumus yang digunakan yaitu sebagai berikut :

Rumus Separated Varians :

$$
t=\frac{\overline{X_{1}}-\overline{X_{2}}}{\sqrt{\frac{s_{1}{ }^{2}}{n_{1}}+\frac{s_{2}{ }^{2}}{n_{2}}}}
$$

Keterangan :

$\bar{X}_{1} \quad=$ Nilai rata-rata skor kelompok eksperimen

$\bar{X}_{2}=$ Nilai rata-rata skor kelompok kontrol

$n_{1} \quad=$ Banyaknya siswa kelompok eksperimen

$n_{2} \quad$ = Banyaknya siswa kelompok kontrol

$s_{1}{ }^{2}=$ varians kelompok eksperimen

$s_{2}{ }^{2}=$ varians kelompok kontrol

Untuk mendapatkan hasil yang lebih akurat analisis uji-t. Cara manual untuk menghasilkan interpretasi, maka $t_{\text {hitung }}$ tersebut harus dikomparasikan dengan $t_{\text {tabel }}$ dengan indikator taraf signifikan $5 \%(0,05)$. Apabila thitung lebih besar daripada $t_{\text {tabel }}$ $\left(t_{\text {hitung }}>t_{\text {tabel }}\right)$, maka terdapat perbedaan yang signifikan antara kedua variabel atau sampel. Sedangkan apabila thitung lebih kecil dari $t_{\text {tabel }}\left(t_{\text {hitung }}>t_{\text {tabel }}\right)$, maka tidak terdapat perbedaan yang signifikan antara kedua variabel atau sampel.

\section{HASIL PENELITIAN DAN PEMBAHASAN}

Berdasarkan data dalam penelitian ini adalah skor hasil belajar videografi siswa kelas XI DKV sebagai akibat dari penerapan e-modul berbasis project based learning pada kelompok eksperimen dan 
bahan ajar buku sekolah eletronik pada kelompok kontrol.

\section{A. Deskripsi Data Hasil Post-test Siswa Kelompok Eksperimen}

Berdasarkan data pengukuran hasil belajar kognitif mata pelajaran Videografi terhadap 15 siswa kelompok eksperimen, diperoleh data distribusi frekuensi skor post-test hasil belajar kognitif mata pelajaran Videgrafi kelompok eksperimen diketahui bahwa skor tertinggi siswa adalah 39 dan skor terendah siswa adalah 25. Adapun distribusi data hasil post-test kelompok eksperimen disajikan pada Tabel 4 berikut.

Tabel 4. Distribusi Frekuensi Hasil Post Test Kelompok Eksperimen

\begin{tabular}{|l|c|c|c|c|}
\hline Interval & Nilai Tengah & Frekuensi Observasi (F) & Frekuensi Relatif(\%) & Frekuensi Komulatif (\%) \\
\hline $25-27$ & 26 & 2 & 13.33 & 13.33 \\
\hline $28-30$ & 29 & 3 & 20.00 & 33.33 \\
\hline $31-33$ & 32 & 3 & 20.00 & 53.33 \\
\hline $34-36$ & 35 & 4 & 26.67 & 80.00 \\
\hline $37-39$ & 38 & 3 & 20.00 & 100.00 \\
\hline \multicolumn{2}{|r|}{ Jumlah } & 15 & 100,00 & 279.98 \\
\hline
\end{tabular}

Berdasarkan hasil perhitungan,

data hasil belajar Videografi kelompok didapatkan panjang kelas interval dari

Eksperimen seperti pada Tabel 5 berikut.

Tabel 5. Kategori Data Hasil Belajar Videografi Kelompok Eksperimen

\begin{tabular}{|l|l|c|c|}
\hline Rentangan Skor & Kategori & Frekuensi & Persentase (\%) \\
\hline $30 \leq \bar{X}$ & Sangat Tinggi & 10 & 66.67 \\
\hline $23 \leq \bar{X}<30$ & Tinggi & 5 & 33.33 \\
\hline $17 \leq \bar{X}<23$ & Sedang & 0 & 0.00 \\
\hline $10 \leq \bar{X}<17$ & Rendah & 0 & 0 \\
\hline $\bar{X}<10$ & Sangat Rendah & 0 & 0 \\
\hline Jumlah & & 15 & 100 \\
\hline
\end{tabular}

Berdasarkan Tabel diatas data hasil belajar Videografi kelompok Eksperimen dapat disajikan dalam bentuk histogram seperti Gambar berikut.

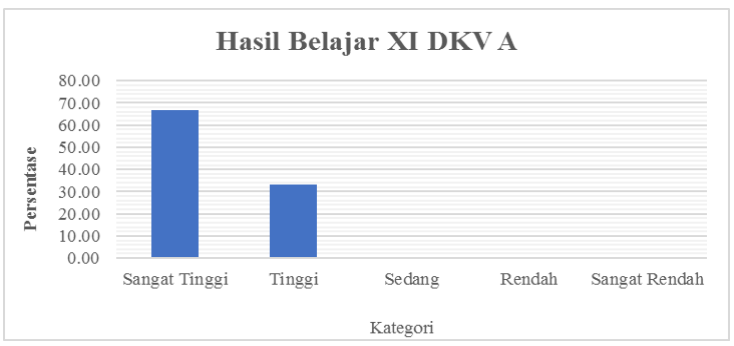

Pada Gambar diatas dapat diketahui bahwa hasil belajar Videografi kelompok eksperimen sebanyak $66.67 \%$ berkategori sangat tinggi, sebanyak $33.33 \%$ berkategori tinggi, serta tidak ada siswa yang memiliki hasil belajar Videografi berkategori sedang, rendah dan sangat rendah.

\section{B. Deskripsi Data Hasil Post-test Siswa Kelompok Kontrol}

Berdasarkan data pengukuran hasil belajar kognitif mata pelajaran Videografi terhadap 15 siswa kelompok kontrol, diperoleh data distribusi frekuensi skor post-test hasil belajar kognitif mata pelajaran Videografi kelompok control diketahui bahwa skor tertinggi siswa adalah 35 dan skor terendah siswa adalah 21. Adapun distribusi data hasil post-test 
kelompok kontrol disajikan pada Tabel berikut.

Tabel 6. Distribusi Frekuensi Hasil Post Test Kelompok Kontrol

\begin{tabular}{|c|c|c|c|c|}
\hline Interval & $\begin{array}{c}\text { Nilai } \\
\text { Tengah }\end{array}$ & $\begin{array}{c}\text { Frekuensi } \\
\text { Observasi (F) }\end{array}$ & $\begin{array}{c}\text { Frekuensi } \\
\text { Relatif(\%) }\end{array}$ & $\begin{array}{c}\text { Frekuensi } \\
\text { Komulatif (\%) }\end{array}$ \\
\hline $21-23$ & 22 & 3 & 20.00 & 20.00 \\
\hline $24-26$ & 25 & 2 & 13.33 & 33.33 \\
\hline $27-29$ & 28 & 3 & 20.00 & 53.33 \\
\hline $30-32$ & 31 & 2 & 13.33 & 66.67 \\
\hline $33-35$ & 34 & 5 & 33.33 & 100.00 \\
\hline Jumlah & & 15 & 100.00 & 273.33 \\
\hline
\end{tabular}

Berdasarkan hasil perhitungan, didapatkan panjang kelas interval dari data hasil belajar Videografi kelompok kontrol seperti pada Tabel berikut

Tabel 7. Kategori Data Hasil Belajar Videografi Kelompok Eksperimen

\begin{tabular}{|l|l|c|c|}
\hline Rentangan Skor & Kategori & Frekuensi & Persentase (\%) \\
\hline $30 \leq \bar{X}$ & Sangat Tinggi & 5 & 33.33 \\
\hline $23 \leq \bar{X}<30$ & Tinggi & 7 & 46.67 \\
\hline $17 \leq \bar{X}<23$ & Sedang & 3 & 20.00 \\
\hline $10 \leq \bar{X}<17$ & Rendah & 0 & 0.00 \\
\hline $\bar{X}<10$ & Sangat Rendah & 0 & 0.00 \\
\hline Jumlah & & 15 & 100.00 \\
\hline
\end{tabular}

Berdasarkan Tabel diatas data hasil belajar Videografi kelompok Kontrol dapat disajikan dalam bentuk histogram seperti Gambar berikut.

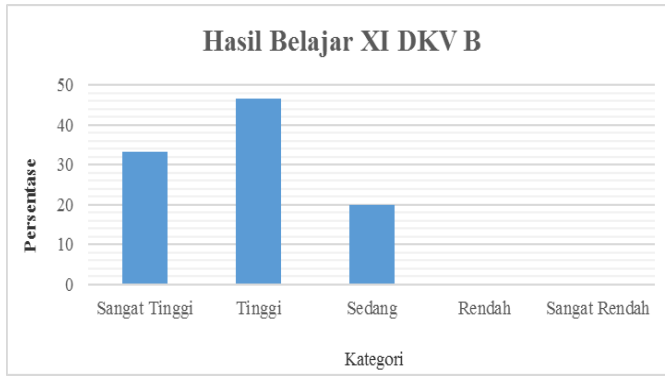

Pada Gambar diatas dapat diketahui bahwa hasil belajar Videografi kelompok eksperimen sebanyak $33.33 \%$ berkategori sangat tinggi, sebanyak $46.67 \%$ berkategori tinggi, sebanyak $20.00 \%$ bekategori sedang, serta tidak ada siswa yang memiliki hasil belajar Videografi berkategori rendah dan sangat rendah.

\section{Analisis Prasyarat Dan Pengujian Hipotesis Uji Normalitas Kelompok Eksperimen}

Berdasarkan hasil output analisis menunjukkan nilai Kolmogrov-Sminov dengan probabilitas (sig) sebesar 0.200 dan nilai Shapiro Wilk dengan probabilitas(a) sebesar 0.750 oleh karena nilai probabilitas kedua nilai signifikan > 0,05 maka ini berarti bahwa data hasil posttest kelompok eksperimen berdistribusi normal yaitu tidak terdapat perbedaan frekuensi sebaran data kelompok eksperimen.

\section{Uji Normalitas Kelompok Kontrol}

Berdasarkan hasil output analisis menunjukkan nilai Kolmogrov-Sminov dengan probabilitas (sig) sebesar 0.200 dan nilai Shapiro Wilk dengan probabilitas(a) sebesar 0.211 oleh karena nilai probabilitas kedua nilai signifikan > 
0,05 maka ini berarti bahwa data hasil posttest kelompok eksperimen berdistribusi normal yaitu tidak terdapat perbedaan frekuensi sebaran data kelompok eksperimen.

\section{Uji Homogenitas}

Berdasarkan hasil output analisis menunjukkan nilai sig. sebesar 0.475 . Oleh karena nilai signifikan $>0,05$, maka data hasil belajar kelompok eksperimen dan kelompok kontrol dikatakan homogen yaitu tidak terdapat perbedaan varians antara kelompok eksperimen dan kelompok kontrol.

\section{Uji HIpotesis}

Hasil uji hipotesis penelitian dengan menggunakan SPSS berdasarkan pengambilan keputusan pada uji hipotesis SPSS adalah sebagai berikut.

Tabel 8. Hasil Uji Hipotesis dengan SPSS

\begin{tabular}{|c|l|c|c|c|}
\hline \multicolumn{2}{|c|}{} & \multicolumn{3}{c|}{ t-test for Equality of Means } \\
\cline { 3 - 5 } \multicolumn{2}{|c|}{ Nilai } & t & df & Sig. (2tailed) \\
\hline \multirow{2}{*}{} & Equal variance assumed & 2.397 & 28 & 0.023 \\
\cline { 2 - 5 } & $\begin{array}{l}\text { Equal variance not } \\
\text { assumed }\end{array}$ & 2.397 & 27.407 & 0.024 \\
\hline
\end{tabular}

Berdasarkan hasil output analisis menunjukan nilai Sig. adalah 0.023. Oleh karena nilai probabilitas siginifikan $<0,05$, maka $\mathrm{H} 0$ ditolak atau $\mathrm{H} 1$ diterima. Sehingga dapat dikatakan bahwa terdapat hasil belajar yang lebih tinggi antara siswa yang belajar menggunakan e-modul project based learning dan siswa yang belajar menggunakan buku sekolah elektronik pada mata pelajaran Videografi siswa kelas XI DKV SMK Negeri 1 Sukasada.

\section{Hasil Respon Siswa}

Dari penyebaran angket respon yang disebarkan kepada 15 siswa pada akhir penelitian untuk mengetahui tanggapan atau respon siswa terhadap penggunaan Emodul berbasis Project Based Learning pada mata pelajaran Videografi. Sebaran skor respon siswa disajikan pada Tabel berikut.

Tabel 9. Sebaran Skor Respon Siswa

\begin{tabular}{|l|l|l|l|}
\hline Rentangan Skor & Kategori & Frekuensi & Persentase \\
\hline $96 \leq \bar{X}$ & Sangat Positif & 3 & 20 \\
\hline $80 \leq \bar{X}<96$ & Positif & 11 & 73.33 \\
\hline $64 \leq \bar{X}<80$ & Cukup Positif & 1 & 6.66 \\
\hline $48 \leq \bar{X}<64$ & Kurang Positif & 0 & 0 \\
\hline $\bar{X}<48$ & Sangat Kurang Positif & 0 & 0 \\
\hline Jumlah & & 15 & 100 \\
\hline
\end{tabular}

Berdasarkan Tabel diatas data respon siswa terhadap penggunaan E-modul berbasis Project Based Learning pada mata pelajaran Videografi dapat disajikan histogram, pada Gambar berikut.

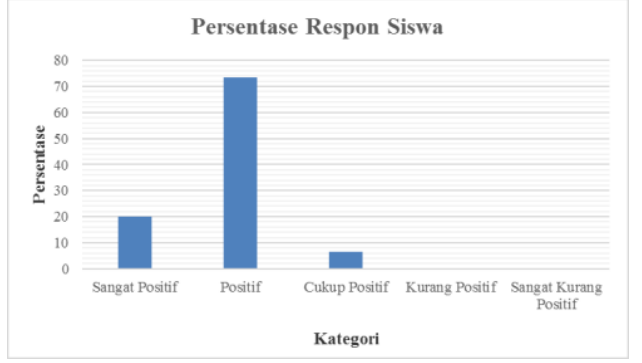


Pada Gambar diatas dapat diketahui bahwa respon siswa terhadap penggunaan E-modul berbasis Project Based Learning pada mata pelajaran Videografi sebanyak $20 \%$ berkategori sangat positif, sebanyak $73,33 \%$ berkategori positif, $6,66 \%$ berkategori cukup positif serta tidak ada respon siswa terhadap e-modul berbasis Project Based Learning yang berkategori kurang positif dan sangat kurang positif.

\section{E. PEMBAHASAN}

Hasil penelitian meliputi analisis deskriptif dan analisis statistik yang mengungkap pengaruh variabel bebas terhadap variabel terikat. Anggota populasi dalam penelitian ini adalah siswa kelas XI DKV yang terdiri dari kelas XI DKV A dan Kelas DKV B di SMK Negeri 1 Sukasada. Jumlah anggota populasi yang telah ditentukan dalam penelitian ini adalalah 30 siswa. Dalam penelitian ini, pemilihan sampel yang digunakan sebagai kelas eksperimen dan kelas kontrol dilakukan uji kesetaraan terlebih dahulu untuk meyakinkan bahwa kelas benar-benar dalam keadaan setara dari segi kemampuan akademisnya. kemudian dilanjutkan dengan menentukan kelas eksperimen dan kelas kontrol dengan cara melihat nilai rata-rata kelas yang tertinggi dari kedua sampel penelitian yang sudah didapatkan. Sehingga, diperoleh kelas XI DKV A sebagai kelas eksperimen dan kelas XI DKV B sebagai kelas control. Setelah diberi perlakuan pada kelas eksperimen diberikan tes akhir, begitu pula pada kelas kontrol. Analisis dari hasil penelitian didapat bahwa rata-rata post-test hasil belajar Videografi yang dicapai siswa pada kelompok eksperimen adalah 32.6 sedangkan rata-rata post-test hasil belajar Videografi untuk kelompok kontrol sebesar 28.80. Dengan demikian, rata-rata post-test hasil belajar Videografi pada kelompok eksperimen lebih besar dibandingkan kelompok kontrol.

Berdasarkan hasil uji normalitas dan homogenitas varians, maka pengujian hipotesis dalam penelitian ini dihitung secara satistika yakni dengan menggunakan uji-t. Hasil uji normalitas pada penelitian ini tidak terdapat perbedaan frekuensi sebaran data hasil belajar Videografi kelompok eksperimen (normal) sedangkan hasil uji homogenitas varian pada penelitian ini tidak terdapat perbedaan varians data hasil belajar Videografi antara kelompok eksperimen dan kelompok kontrol (homogen). Hasil tersebut menunjukan menunjukkan bahwa terdapat perbedaan yang tinggi terhadap hasil belajar Videografi antara siswa yang belajar dengan menggunakan media pembelajaran $e-$ modul Project Based Learning dengan media pembelajaran berupa media power point Videografi terhadap hasil belajar siswa kelas XI DKV A dan XI DKV B SMK Negeri 1 Sukasada tahun ajaran 2017/2018.

\section{REFERENSI}

[1] Agustini, K., \& Wahyuni, D. S. (2013). Pengaruh Penggunaan Simulasi Binary Tree Berbasis Cai. Jurnal Pendidikan Indonesia, 162-172.

[2] Wicaksono, A. R. (2015). Perancangan dan Implementasi Elearning Pendukung Project Based Learning. Seminar Nasional Teknologi Informasi dan Komunikasi (SENTIKA).

[3] Sugihartini, N., Agustini, K., \& Pradnya, G. A. (2017). Penerapan ELearning Di Smkn 2 Tabanan. Jurnal Widya Laksana, 17-23.

[4] Putrayasa, I. B. (2013). Buku Ajar Landasan Pembelajaran. Singaraja: Undiksha Press

[5] Sugiyono. (2014). Metode Penelitian Pendidikan Pendekatan

Kuantitatif, Kulitatif, dan R\&D. Bandung: Alfabeta.

[6] Gunadharma, A. (20011). Pengembangan Modul Elektronik sebagai Sumber Belajar Untuk Mata Kuliah Multimedia Design Pengembangan Modul Elektronik sebagai Sumber Belajar Untuk Mata Kuliah Multimedia Design. Skripsi (tidak diterbitkan). Jurusan Teknologi Pendidikan, Fakultas IImu Pendidikan: Universitas Negeri Jakarta

[7] Kemendikbud. (2013). Model Pembelajaran Berbasis Proyek (Project Based Learning). Jakarta: Kementrian Pendidikan dan Kebudayaan. 
[8] Grant, M. M. (2002). Getting a Grip on Project Based Learning: Theory, Cases, Recomandations.

[9] Hamalik, O. (2001). Kurikulum dan Pembelajaran. Jakarta: Puspa.

[10] Sudaryono, G. M. (2013). Pengembangan Instrumen Penelitian Pendidikan. Yogyakarta: Graha IImu.

[11] Sukardi. (2009). Metodologi Penelitian Pendidikan. Jakarta: Bumi Aksara.

[12] Putra, K. W. B., Wirawan, I. M. A., \& Pradnyana, G. A. (2017).

Pengembangan E-Modul Berbasis
Model Pembelajaran Discovery Learning Pada Mata Pelajaran "Sistem Komputer" Untuk Siswa Kelas $X$ Multimedia SMK Negeri 3 Singaraja. Jurnal Pendidikan Teknologi dan Kejuruan, 14(1). 